\section{Koks i kulissen}

af stipendiat, dr.phil. Lotte Thrane

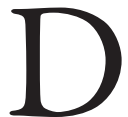
en 16. september 1912 er der sæsonpremiere på Casino-teatret i København. Københavnerne skal ind og se fru Olga Hansen-Ott, enke efter en af byens store mænd, debutere som dramatiker. Hendes nærmeste ved, at hun har skrevet noveller i nogle år, men først nu træder hun frem under eget navn. Stykket hedder Portnerens Datter, og det annonceres som "et Folke-Skuespil i 4 Akter". Der lokkes med navne som tidens storcharmør Holger Reenberg, en lovende ung Arne Weel og Casinos primadonna, fru Gerda Christophersen. Flere blandt publikum kommer sikkert også for at se forfatterinden, om hvem der går en del historier.

Stykket handler om portnerdatteren Anna, der bliver gravid med en charmør, der viser sig at være en rigtig skidt knægt - han spilles af Holger Reenberg - og om hvordan hun selv og ikke mindst hendes familie tackler problemet. Det ender godt; den ædruelige og retskafne Ludvigsen, der har elsket Anna i løn, tilbyder hende og barnet sin støtte, dvs. ægteskab. En ret banal og ikke uforglemmelig historie, havde det ikke været for de rappe replikker, den vittige dialog og især det problem, stykket debatterer: den løgnagtige seksualmoral. Som da den unge mor ser sit barn første gang og udbryder:
"Gudskelov, en dreng! For så kan han ingen uægte børn få - sådan at det gør ham noget!" Og lidt senere tilføjelsen: "For ugifte mænd har aldrig børn, det er kun de ugifte kvinder, der har dem."

Ironien er til at tage og føle på, for portnerens datter er vokset op overfor Fødselsstiftelsen, den institution i Amaliegade i København, hvor ugifte kvinder kunne føde og eventuelt efterlade deres børn, uden at opgive hverken deres eget eller faderens navn til myndighederne. I hele Annas liv har hendes portner-far tordnet om "skammen" og peget over på Fødselsstiftelsen, når endnu en højgravid kvinde sneg sig ind for at føde endnu et "uægte" barn. Og selvom Anna reddes på stregen af den gode Ludvigsen, står hendes udsagn om "det knusende uretfærdige" i samfundets kønsmoral meget tydeligt.

Det uægteskabelige barn er også tema i fru Otts næste stykke, Lille Eva, der spilles på Folketeatret i 1913 og siden på Det ny Teater; begge steder med stor succes (henholdsvis 49 og 57 opførelser). Her er det det voksne barns synsvinkel, dets behov for at kende sine rødder, så at sige. Ida, den forældreløse, har i mange år modtaget en pung med et pengebeløb en gang om måneden, med en sympatisk huslæge som mellemmand. Idas ugifte mor er for længst død, så hun antager, at pengene kommer fra den far, der ikke vil eller kan give sig til kende. Veninden Eva, der både ryger cigaretter og drikker likør og læser de forbudte bøger fra sine forældres bibliotek, får nys om historien og påtager sig opgaven med at finde Idas far og fà ham til at stå frem. Nogle misforståalser og intriger skal lige ryddes af vejen før den overraskende sandhed kommer på bordet, og dette stykke ender også i en lidt for fad 
og villet idyl, hvor Ida og budbringeren af pungen får hinanden, mens den dobbeltmoralske og skvattede barnefader lover bod og bedring.

Stærkt står imidlertid ordvekslingerne mellem Eva og hendes jævnaldrende, hvor tunge og kontroversielle emner som troskab, løgn, seksualitet og kønsmoral flettes ind i den vittige dialog. Ott er altid kvinde for at punktere patos eller selvfedme i et udsagn. Som der, hvor Evas fætter tilstår om sit forhold til en stuepige, der har afpresset ham, så han har betalt hende alle sine lommepenge: "Men så en aften, da havde jeg næsten besluttet mig til at begå selvmord, for jeg kunne da ikke blive ved at leve uden lommepenge resten af livet, vel?"

Mænd er generelt nogle pjok i Olga Otts dramatiske univers, men hun kan også være kritisk overfor kvinder. Hendes sympati er dog utvetydigt hos de unge og de kontroversielle, der tør tale Roma midt imod, og som tør gå på tværs af den offentlige mening. En af hendes frimodige heltinder, der blev spillet af en ung Ellen Gottschalch på Det ny Teater i 1918, bader i Øresund og cykler hver dag ind til København og hader parfume og elsker naturen, alt imens hun tager studentereksamen og udtaler, at hun ikke nødvendigvis vil giftes. Det er det nye, sporty og handlekraftige kvindebillede, der her toner frem, den kulturradikale elites kvindeideal. Kvinderne havde omsider fået valgret i 1915, og Olga Ott havde - i modsætning til sin dramatikerkollega Emma Gad - kæmpet helhjertet for sagen. Solidariteten gælder også kvinder, der er kuede eller undertrykte i ægteskaber med voldelige eller despotiske ægtemænd, og dem er der flere af i forfatterskabet. Undtaget er lediggående, bornerte og snobbede fruer fra borgerskabet og et par veldædige hattedamer - de får alle med Olga Otts satiriske krabask. Og så har hun en helt holbergsk faible for kvikke tjenestefolk, der altid ved mere og bedre end deres herskab, fordi de har fingrene nede i materien og begge ben på jorden. Som kokkepigen siger til stuepigen om to nyskilte fruer: "Så sidder de her om aftenen og drøfter ægteskabets helvede, eller også er det nye snitmønstre til chemiser og bluser." 1

Portnerens Datter gik godt; det blev opført 25 gange i sæsonen 1912-13. Med sine to første teaterstykker, og bestemt også med de tolv, der fulgte, demonstrerer forfatterinden, at hun har meninger om sin tid og om de mere eller mindre ormstukne moralbegreber, hun kan have mødt i sin egen omgangskreds.

Men hvem var hun egentlig?

Olga Juliette Marie Hansen-Ott, født Sørensen, voksede op i Randers på et lille provinshotel, som hendes forældre drev. I et interview til Vore Damer i 1916 fortæller hun, hvordan hun tidligt lærte sig at lytte til de forskellige nuancer i måden folk talte på - og materiale var der nok af på hotellet, med gæster, der kom og gik. Skrive ville hun, og her støttede hun og barndomsveninden Karin Michaëlis, født Brøndum, hinanden. De rejste sammen til København i begyndelsen af 1890 'erne; frk. Brøndum officielt for at blive klaverlærerinde, frk. Sørensen officielt for at arbejde på kontor.

Den lange slanke Olga og den lille buttede Karin kom hurtigt ind i kredsen af unge digtere knyttet til månedsskriftet Ungt Blod; her fik folk som Jeppe Aakjær, Viggo Stuckenberg, Sophus Michaëlis og Louis Levy trykt deres tekster. Olga har sikkert haft et lidt distanceret forhold til 
Olga Hansen-Ott

(1871-1929), fra

1916 Olga Ott.

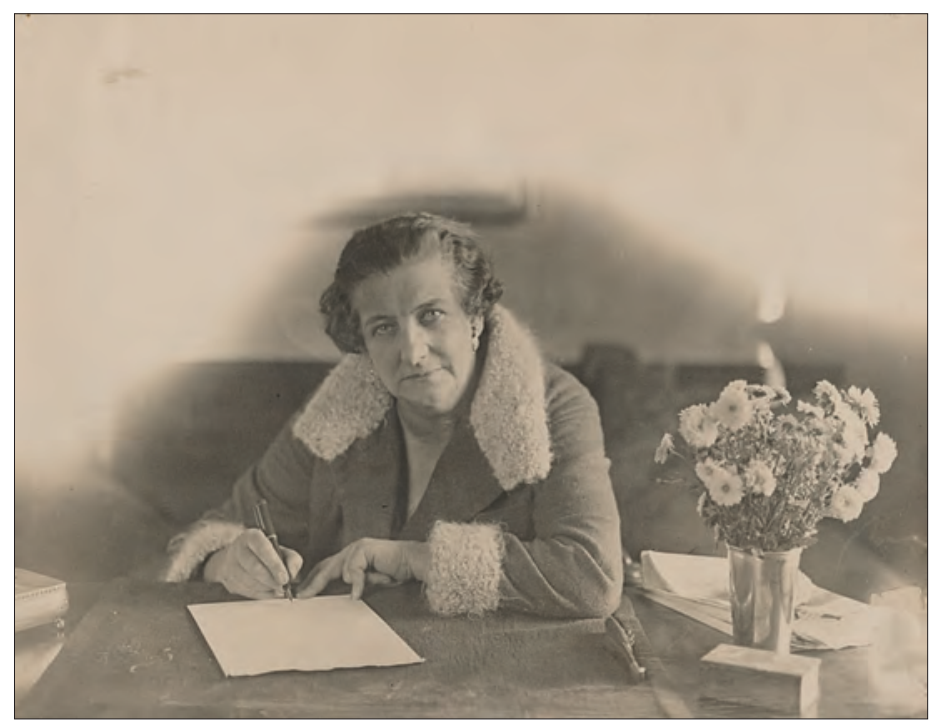

gruppens sen-symbolistiske sortsyn, for det hun især skrev i disse år var mundrette og vittige sange og dialoger til nogle af de mange cabareter og revyer, som hovedstaden lagde hus til i 1890'erne. Og så mødte hun kærligheden i 1896 - hun og den udkårne spillede med i den navnkundige Cycle-Revy det år; han som en uheldig cykelrytter, hun som hans drømmesyn og så var hun desuden revyens tekstforfatter, sammen med sin musikerbror. Revyen hed Paa Landevejen ud, og den udkårne i cykelrytter-rollen hed Johannes HansenOtt.

Hansen-Ott var - eller blev - en af tidens helt store iværksættere og publicister. Selvom han som 23-årig i 1896 var i gang med at gøre lynkarriere i stormagasinet Magasin du Nord, havde han allerede erfaringer som journalist og bladmand. Han skrev, som den første i Danmark, om sport i venstreavisen Dannebrog i begyndelsen af halvfemserne, og han udgav fra 1895 både ugeavisen Cyclen og det populære satireblad Klods-Hans, der i ord og tegninger tog aktuelle, også politiske, emner op og gjorde tykt grin med dem. Hansen-Ott skulle komme til at stå for mange, og mange forskelligartede initiativer i de kommende år - mest markant er den ublodige 'paladsrevolution', som han og journalisten Henrik Cavling gennemførte i Politikens hus i juledagene 1904. Herefter blev Cavling chefredaktør og Hansen-Ott bladhusets direktør.

Johannes og Olga flyttede som nygifte ind i en stor lejlighed på Østerbro i København. Omgangskredsen tilhørte, som ægteparret selv, tidens frisindede, kulturradikale kleresi - en udsøgt blanding af kunstnere, reformpædagoger, journalister og universitetsfolk. Også politisk tilhørte man avantgarden - i 1905 var ægteparret med til at stifte Det radikale Venstre. Et middagsselskab i lejligheden på mezzaninen i Ribegade har kunnet mønstre brødrene Brandes, Henrik Cavling, grønlandsfarerne Knud Rasmussen og Mylius-Erichsen, skolemanden C.N. Starcke, erhvervsmanden Egmont $\mathrm{H}$. 


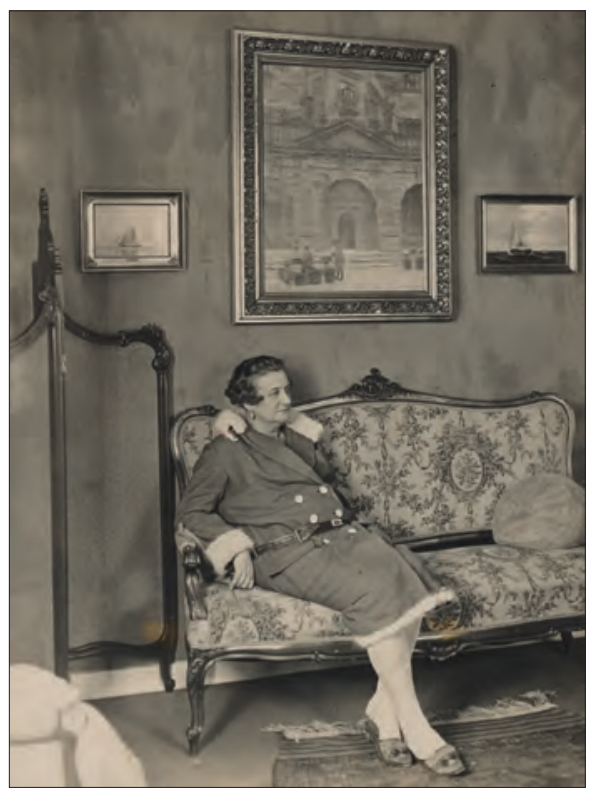

Petersen, tegnerne Alfred Schmidt, Storm P. og Gerda Wegener, og forfattere som Louis Levy, Johs. V. Jensen, Edith Rode og Karin og Sophus Michaëlis.

Da Johannes dør under en blindtarmsoperation i 1906 står Olga pludselig alene med tre børn på otte, seks og tre, og næsten uden midler; selv livsforsikringen havde hendes mand belånt for at få penge til nye initiativer. $\mathrm{Nu}$ er det slut med festivitas og store middagsselskaber; sølvtøjet pantsættes, familien flytter til en lille fjerdesalslejlighed længere nede af gaden, de to ældste børn får friplads på Ingrid Jespersens skole, og Olga bliver annonceagent.

Forfatterskabet ligger ikke i dvale efter denne økonomiske deroute; Olga Ott, som hun herefter kalder sig, skriver en børnebog under eget navn og almanakhistorier til ugeblade som Vore Damer, Illustreret Tidende og Verdensspejlet. Men teatret er det, hun brænder for. Hun
Olga Ott var forfatter af revytekster og noveller 1896-1911 (under pseudonymet 'Mortensen'), af borne-og ungdomsboger 1906-1921. Romandebut 1923 (Vi tre. En Roman i Breve) s.m. datteren Estrid Ott, amerikansk oversettelse 1924. Debut som dramatiker 1912, herefter elleve premierer de naste 14 år på Folketeatret, Dagmarteatret, Odense Teater, Aarhus Teater og isar Det ny Teater. Olga Ott er omtalt i Svend Dabl: Dansk Skønlitterært Forfatterleksikon 19001950, bind 3, 1964, men ellers vil man lede forgaves efter hende i nyere litteraturhistorier, teaterhistorier, leksik a og andre oversigtsverker. Hendes mere beromte datter, forfatteren Estrid Ott (1900-1967) kan have haft en finger med i spillet her. Men det er en belt anden historie.

sender sit allerførste stykke, Tidens Mand, ind til Det kongelige Teater i 1911 og har en lovende samtale med direktøren, Karl Mantzius. Men så kommer der ny direktør, og han vender tommelfingeren nedad.

I Olga Otts brevveksling med Georg Brandes omtales skuffelsen - og især hvordan en "LL" har hånet hende og belært hende om forskellen på kunst og underholdning. Vi ved ikke, hvad Brandes svarede hende, men vi ved hvem "LL" er: Det er den litterære rådgiver fra ungpigeårene, der siden blev husven hos ægteparret Hansen-Ott, forfatteren Louis Levy. Og øjensynlig blev han mere end det - Louis Levy fik et barn med Olga, en dreng, der blev født 1911 - året før hendes debut på Casino.

Portnerens Datter og Lille Eva kunne ses som en dramatisering af forfatterindens egne erfaringer og især som en hævnakt mod Louis Levy - og det skal der nok have været flere blandt publikum, 
der mente, det var. Men stykkerne er nu mere end det. Forfatteren Anton Andersens karakteristik af Emma Gad, der også skrev for scenen i disse år, kunne sagtens passe på Olga Ott: “... hun ser godt, hun ser selv, og hun formaar at forme en Replik mesterligt. Dertil raader hun over et udmærket Humør, ægte dansk Lune, en let og fin Satire, et lyst, sympatetisk Blik."2

Trods det "lyse, sympatetiske blik", der var Olga Otts måde at tackle problemer på, var det ikke det rene pjat, hun skrev - og det er også givtigt at sætte hendes kunstneriske bearbejdninger af egne smertepunkter ind i den tidstypiske fortælling, der kaldes Sadelighedsfejden. Den udspillede sig i den danske offentlighed i 1880 'erne, og selvom der var gået mere end tyve år, var der stadig tydelige efterdønninger af debatten, der havde drejet sig om seksualitet - den mandlige versus den kvindelige - med følgende spørgsmål sat til diskussion: Skal begge køn følge parolen om fri seksualitet (Brandes-fløjen), eller bør begge køn pålægge sig kyskhed før ægteskabet, den såkaldte Handske-Moral, som forfatteren Bjørnstjerne Bjørnson - stærkt støttet af Dansk Kvindesamfund - forfægtede. Spørgsmålet blev kun stillet til borgerskabets mænd og kvinder, selvom det udsprang af det indtryk, enhver kunne få, hvis han eller hun turde bevæge sig ud i de hurtigt voksende brokvarterer i København; her var elendige levevilkår, hvor store familier og flere generationer ofte delte ét værelse og alt for få senge og her var masser af synlig prostitution.

Olga Ott placerer sig på Bjørnsonfløjen med disse to stykker dramatik. Men hun skulle skifte holdning - eller snarere nuancere sin holdning - med det, der er hendes allersidste teaterstykke. Det hedder Erotiske Løgne, er fra 1928, og det foreligger kun som manuskript.

Stykket handler om en enke, Louise, med voksne børn - og med en elsker. Men det handler først og fremmest om alle de løgne, hun spinder sig selv ind $i$, for at kunne opretholde billedet af sig selv som en respektabel kvinde. Hun lyver for børnene, for ikke at skuffe elskeren, og hun lyver for elskeren, for ikke at skuffe børnene. Elskeren Oluf Blicker er nu også fuld af løgn; han har flere elskerinder end Louise, og selvom forfatterinden forsøger at udstille ham som skurk, afslører hun også en markant fascination af denne mandstype, af forføreren eller "dyretæmmeren", som han kaldes af en allestedsnærværende og kvik stuepige. Blicker er et af de få 'hele' mandsportrætter i Olga Otts forfatterskab.

Trods titlen er stykkets tema driften, den ulyksalige seksualdrift, der er kommet for at blive, så at sige. Kvinders seksualdrift, vel at mærke! Det meste af tredje akt er helliget en diskussion mellem to kvinder af det "erotiske hysteri", som er Olga Otts navn for driften - "det Helvede, hvorfra man aldrig slipper ud - og hvor Ilden aldrig slukkes, fordi det er vor egen usalige Lidenskab, der holder Baalet vedlige."

Det er her Olga Ott nærmer sig Brandes-fløjens position i Sædelighedsfejden. Den fri seksualitet for begge køn er i 1928 nærmest en kendsgerning, men den naturalistisk-pessimistiske lære var, at det ikke har gjort menneskene lykkeligere snarere det modsatte. Elskeren Blicker går rastløst og donjuanistisk fra favn til favn, elskerinden Louise er en slave af sin egen lyst. Olga Ott er her tæt på at kunne tage sin misantropiske, godt nok afdøde forfatterkollega og Strindberg-beundrer Gustav 
Wied under armen og udbryde et "det er synd for menneskene!"

Dansk teater prægedes i 1920'erne stadig af den naturalisme, der var indført i 1880'erne, så Olga Otts dramatik kunne stadig spilles - og blev det. Forfatterinden omtaler i et interview i 1928, at hun netop har fuldendt et nyt stykke - "mit hidtil bedste". Det skal indleveres til Det kongelige Teater, og Poul Reumert har på forhånd sagt ja til at spille den mandlige hovedrolle. Det er Erotiske Logne.

Bornertheden lå dog som et tungt, uldent tæppe over ikke mindst nationalscenens repertoirevalg, så Erotiske Logne, der blev indleveret anonymt, var for stærk kost i 1928. Olga Ott dør i januar 1929 efter nogen tids sygdom, og hendes bedste og mest ærlige stykke dramatik kom tilbage i skuffen.

Noter

1 Stridens able, 1916.

2 Anton Andersen: Danske Forfatterinder i det nittende Hundredaar, 1896, s. 223. 